\title{
The Origins and Arrival of the Earliest Domestic Animals in Mainland and Island Southeast Asia: A Developing Story of Complexity
}

\author{
Philip J. Piper
}

Peter Bellwood's key archaeological research interests have focused on the Neolithic transition and the migration of agricultural populations from southern China southwards through Mainland and Island Southeast Asia. An important aspect of this, probably the most significant transformation in human behaviour in prehistory, was the reshaping of subsistence strategies from foraging and vegeculturel arboriculture to crop production and animal management. When Peter initially drew together the evidence for the migration of Austroasiatic speakers across Mainland Southeast Asia and Austronesianspeaking peoples from Taiwan into Island Southeast Asia and on into the Pacific, he proposed that they transported three domestic animals with them - the pig, dog and chicken. In the almost complete absence of zooarchaeological evidence, this proposal was based primarily on linguistic reconstructions and evidence for the introduction of domestic varieties to Melanesia and the Pacific Islands. Now, and with considerably more information on the presence and/or absence of domestic/managed animals from archaeological sites in Mainland and Island Southeast Asia than was available three decades ago, I reassess the zooarchaeological evidence for domestic animal introductions with some of the earliest proposed agricultural communities in the region.

\section{Introduction}

Since the 1970s, Peter Bellwood's archaeological interests have focused particularly on investigating the emergence of agriculture in Southeast Asia (Bellwood 1976, 1997, 2001, 2005, 2013; Diamond and Bellwood 2003). Peter has been a strong advocate of the farming/ language dispersal hypothesis and has been a main proponent of the migration of agricultural populations, ultimately from southern China, through Mainland and Island Southeast Asia (ISEA) as the main mechanism explaining the geographic distribution of closely related languages and peoples across the region today (Bellwood 1996, 2005, 2013; Bellwood and Dizon 2005). He has argued that these migrating human populations brought with them new modes of sedentary settlement and agricultural life-ways for the first time, as well as a suite of new material culture. 


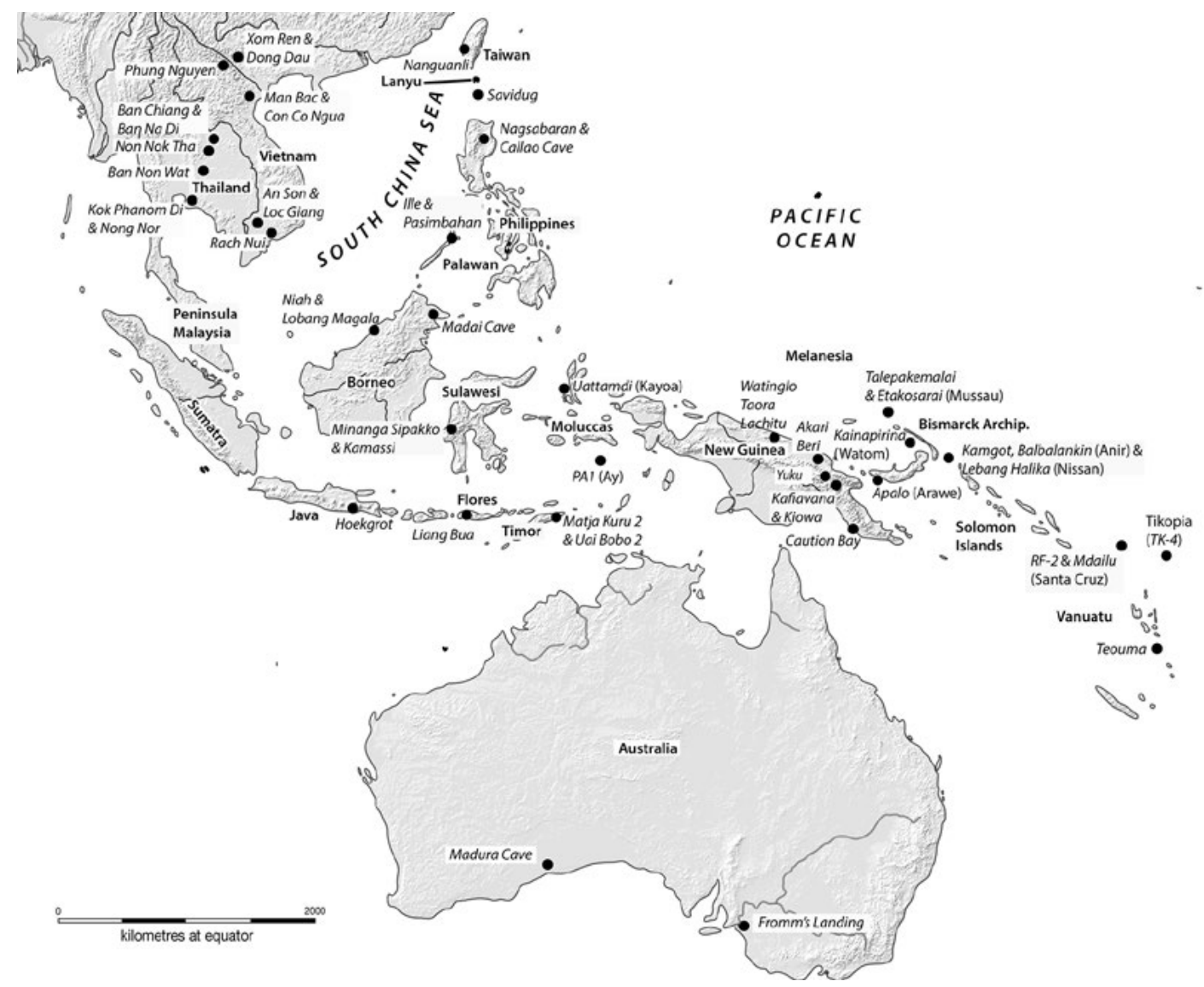

Figure 15.1 The geographic locations of sites (in italics) where domestic animals have been recorded in the archaeological record prior to $3000 \mathrm{BP}$.

Source: P.j. Piper; Base Map: P. Bellwood, ANU Cartography.

In Mainland Southeast Asia (MSEA), the earliest such settlements were purportedly established by Austroasiatic-speaking populations in northern Vietnam, close to the confluence of the Red and Black Rivers. These settlements belong to the Phung Nguyen Culture recorded at sites such as Xom Ren and Man Bac dating from ca. 4000 BP onwards (Figure 15.1; Higham 2004, 2013, 2015). Connections with late Neolithic communities further up the Red River in Yunnan Province are evidenced through similarities in decorative motifs and pottery styles and specialised workshops for the production of nephrite and jadeite beads and bracelets (Rispoli 2007). From northern Vietnam (or southern China) these agricultural populations migrated south along the coast, or followed major river systems such as the Vam Co Dong and Dong Nai into the Mekong Drainage of southern Vietnam where they constructed the settlements of An Son, Loc Giang and Rach Nui, beginning around 4000 cal. BP (Bellwood et al. 2011; Oxenham et al. 2015; Piper and Oxenham 2014). They also moved west through Laos and Cambodia and into central and northern Thailand where the settlements and burial grounds of Ban Non Wat, Non Nok Tha, Ban Chiang and Ban Lum Kao record their initial arrival between $c a$. 3700-3500 cal. BP (Higham 2004; Higham and Higham 2008).

Another proposed movement brought Austronesian-speaking populations from Taiwan into the northern Philippines by $c a .4000 \mathrm{cal}$. BP. From the Philippines they dispersed fairly rapidly south and west into the islands of Southeast Asia (Bellwood 1979, 1997, 2005, 2013). They also moved 
east into the Marianas, and the Bismarck Archipelago, where the Lapita Cultural Complex developed around $c a .3300-3150$ cal. BP. From there they travelled east into the Solomon Islands and Vanuatu, and eventually onwards further into Remote Oceania (Bellwood 2013).

Along with a variety of material culture and new modes of settlement, one of the proposed major economic components transported with these initial farming communities into MSEA and ISEA was the 'big three' of domestic pigs, dogs and chickens. When Bellwood (1975) first suggested that these domestic animals had been introduced into MSEA and ISEA by early agricultural communities it was primarily inferred, firstly by archaeological evidence of the three domesticates intermittently dispersed throughout the region, mostly recorded on islands where no native wild antecedents existed, and secondly by virtue of Proto-Austronesian lexical reconstructions (see Pawley 1966). In 1976, Peter noted of evidence for domestic pigs in ISEA:

The archaeological evidence for pig domestication is South-east Asia is extensive, but all unfortunately of a partly circumstantial nature. No direct osteological evidence for domestication has been published. (Bellwood 1976: 262)

In reference to MSEA in particular, Bellwood (1979: 162-163) remarked that cattle bones (Bos indicus), almost certainly from domestic stock, had been identified associated with human burials at the Neolithic site of Non Nok Tha in northern Thailand, dated in the 1970s to 8000-6000 BP (Higham and Leach 1971, Higham 1975). The pigs and dogs, also associated with the burials, 'were presumably, but not certainly, domesticated as well' (Bellwood 1979: 162-163). In other words, the presence and timing of the appearance of domestic animals across Southeast Asia were a best estimate in the almost complete absence of any identified skeletal remains from archaeological sites.

A confounding factor in linguistic arguments for linking domestic animal translocations to the spread of Austronesian languages in ISEA was the contentious appearance of pig bones dating to 10,000-6000 BP at sites like Kafiavana, Yuku and Kiowa in the highlands of New Guinea (Bulmer 1966, 1975, 1982), and at the sites of Akari and Beri on the coast of the same island by 6000-5000 BP (Swadling et al. 1989). A recent critical reassessment of the chronological integrity of pig bones at Watinglo, Taora and Lachitu has illustrated the problems in relying on associated radiocarbon dates recovered from 'the same' stratigraphic horizons as pig bones to infer radiometric age. The study suggested a much later suid introduction into New Guinea, probably after $3000 \mathrm{BP}$, and succeeding the initial appearance of pigs in Lapita contexts (O'Connor et al. 2011).

In the decades following Peter's comments, the evidence for the introduction of the 'big three' (pigs, dogs and chickens) into SEA in the period before $3000 \mathrm{BP}$ has remained rather circumstantial, and direct zooarchaeological evidence has been scarce. But for pigs to be present in Lapita period sites such as Kamgot, Babase Island, New Ireland, by 3380-2950 cal. BP (MatisooSmith 2007), pigs and chickens at Talepakemalai by 3500-3400 cal. BP (Kirch 1997), ${ }^{1}$ pigs and chickens at Teouma on Vanuatu around 3100-2700 cal. BP (Storey et al. 2010, 2012; Hawkins 2015; Petchey et al. 2015) and dogs in Australia at ca. 3500 BP (Macintosh 1964; Milham and Thompson 1976) they must have all been transported through ISEA prior to these dates.

In this paper, I review the most recent evidence for the origins and routes of migration of the 'big three' across MSEA and ISEA prior to $c a .3000$ BP. Two lines of evidence are drawn upon here: modern and ancient genetics, and the physical remains of domestic animals recovered from archaeological sites. I address three questions: 1. What is the likely origin of the 'big three'? 2. When do they first appear across MSEA and ISEA? and 3. What were their potential routes of translocation?

1 The New Ireland and Talepakemalai dates may soon need to be revised down by a few hundred years to near 3250/3100 BP (Petchey et al. 2015: 103). 


\section{Genetic evidence}

\section{Pigs}

Pig domestication in MSEA is fairly complex, and further complicated by replacement of early domesticates through later translocations southwards into the region from central China (Larson et al. 2010), and what Larson and Fuller (2014: 121) term 'introgressive capture'. Introgressive capture occurs when domestic animals are translocated from one geographic location to another, where they then interbreed with their wild relatives and acquire a 'local' mitochondrial signature. This can, and has been, mistakenly identified as an independent domestication event (see Larson et al. 2005). This is almost certainly the case with the Pacific Clade of pigs, which can be traced from southern China/northern Vietnam through Laos and into Peninsular Malaysia (Larson et al. 2005, 2007). The ultimate origin of these pigs was probably in the Yangtze and Yellow River regions where pig domestication has been recorded as early as 9000 BP (Cucchi et al. 2011). Archaeological and/or modern pig samples with the Pacific Clade signature also occur in Sumatra and Java, and throughout Wallacea and Melanesia, and this has been interpreted as the potential route of migration of human populations, along with their pigs, into the Pacific (Figure 15.2; Larson et al. 2007). However, no specimens with this unique haplogroup have seemingly been found to the west in Cambodia or Thailand where similarities in material culture indicate clear connections with early agricultural communities in southern China and northern Vietnam from ca. 4000-3800 BP onwards (Higham 2004; Bellwood 2013). Yang et al. (2011), based on their mtDNA analyses, argued for small-scale domestication events in MSEA, including within the borders of Thailand. Contra Larson et al. (2010), they also suggested that the Pacific Clade of pigs likely had its origins in ISEA, rather than the Mainland. They based this interpretation on the fact that they found a particular haplogroup (D6 and subgroup M3) linked to the Pacific Clade in both wild and domestic pigs in ISEA populations, though they did not specify where within the islands these were recorded. Although possible, it is unlikely that the Pacific Clade was domesticated in eastern Indonesia (Sus scrofa is only native to the western Indonesian islands of Sumatra, Java and Bali) and transported back into MSEA. This distinctive phylogenetic grouping has been recorded in numerous wild boars in Yunnan Province of southern China, northern Vietnam and Laos where the haplotype is likely to have originated (similar to the Pacific Clade), and moved southwards as part of the Austroasiatic agricultural population migrations (Larson et al. 2010).

Lum et al. (2006) also identified a MSEA origin, possibly Vietnam, for the 'tusker' pigs of Vanuatu, and linked their introduction with the expansion of Lapita at $c a .3200$ BP. They made a tentative connection between pig translocations and the distribution of Austronesian languages but did not specify a particular route of human migration bringing the 'tuskers' to Vanuatu.

No pigs with the Pacific Clade signature have been recorded in either Taiwan or the Philippines, precluding these islands as the point of departure eastwards into the Pacific for these domestic pigs (Larson et al. 2007). In contrast, some modern, and ancient Philippine pigs possess a unique haplotype stemming from the island of Lanyu, located between the northern Philippines and southern Taiwan (Figure 15.2; Larson et al. 2010). Though the Lanyu pigs still cluster with their relatives, Mainland East Asian Sus scrofa, their genetic distance would seem to indicate that they separated long enough ago to become an island native (Larson et al. 2010; Wu et al. 2007). No wild pigs exist on Lanyu nowadays (if they ever did), and only their domestic descendants remain. Interestingly, a study of modern domestic pigs in the Philippines identified several Lanyu signatures in the Cordillera region (Herrera 2010), indicating that the Lanyu haplotype had been introduced to Luzon Island sometime in the past. There is, however, no evidence yet of the expansion of this unusual haplotype beyond the Philippines during prehistory. 
In ISEA, domesticated varieties of the Eurasian wild boar (Sus scrofa) are not the only suids to have been translocated between islands. There is genetic evidence to suggest the translocation of the Sulawesi warty pig (S. celebensis) from Sulawesi to offshore islands, as far as Flores, Timor, Halmahera and Roti (Groves 2007). Groves $(1981,2007)$ has suggested that the Sulawesi warty pig might have been deliberately introduced as a domesticate across parts of Wallacea prior to the introduction of $S$. scrofa. This raises an interesting question about the status of pig domestication in ISEA in the mid-Holocene (addressed below), and whether the Eurasian wild boar was really the first domestic pig species in the region.

\section{Chickens}

The majority of published chicken genetic research undertaken so far has focused primarily on the origins of domestic fowl in Asia and MSEA (Fumihito et al. 1996; Liu et al. 2006; Kanginakudru et al. 2008), and their routes of translocation across Oceania and on to South America (Storey et al. 2008, 2010, 2012, 2013). Less emphasis has been placed on the timing of their entry and routes of movement across ISEA, due to insufficient data to link specific modern chicken haplogroups to definitive ancient domestication centres and lineages through ISEA and into Oceania (Storey et al. 2013). There does seem to be consensus between many researchers that there were multiple domestication centres for chickens in India (Kanginaduru et al. 2008), Thailand (Fumihito et al. 1996), South and southwest China and/or surrounding areas (Liu et al. 2006), and potentially all the above (Storey et al. 2013). Storey et al. (2013) have shown that repeatable sequences on chicken bones from the 3700-3500 cal. BP Neolithic site of Ban Non Wat in Thailand are identical to those recorded in 3250-2950 cal. BP chicken remains from Teouma site on Vanuatu. This at least provides a potential point of origin for the domestic chickens of MSEA and an 'end' point of movement across ISEA in the Pacific.

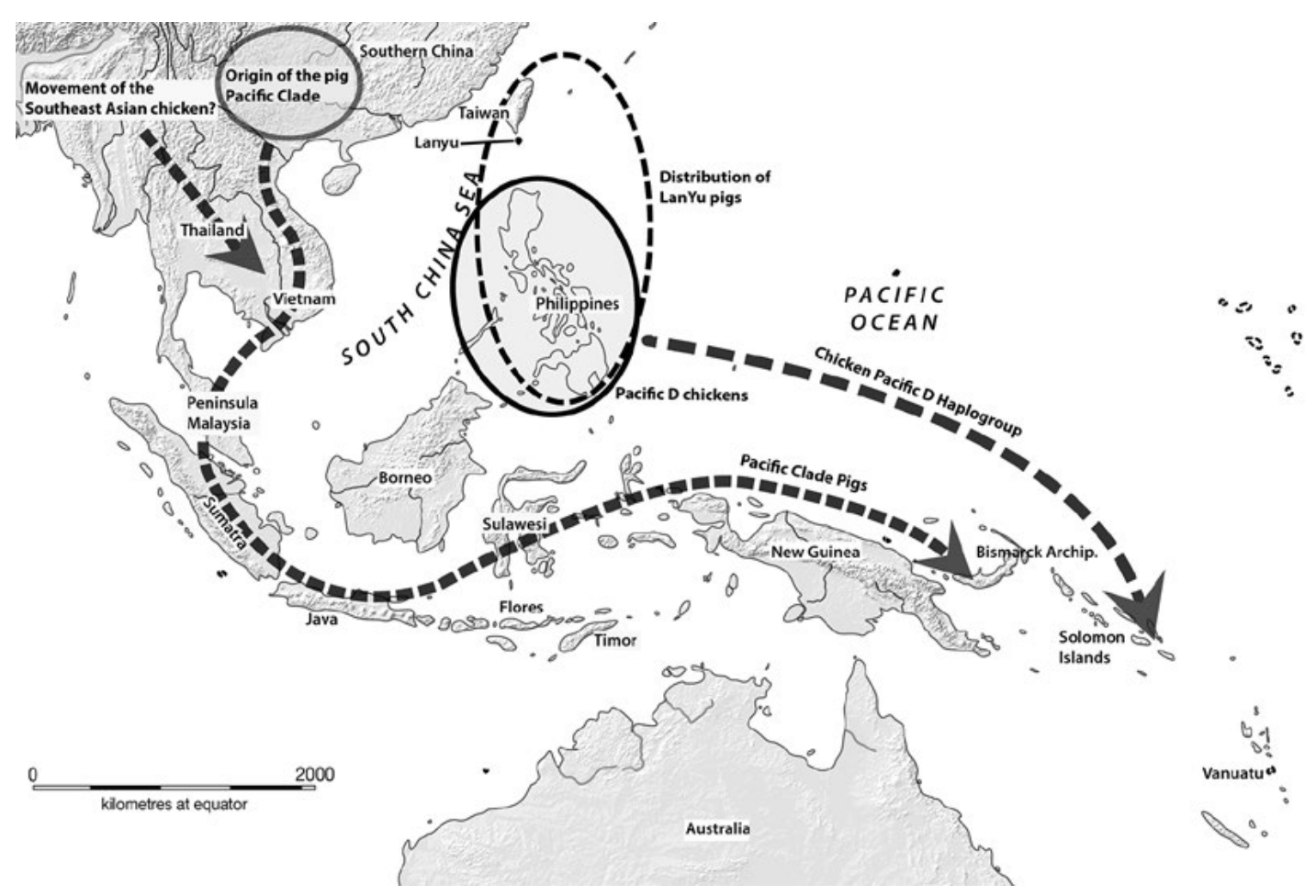

Figure 15.2 The proposed points of origin and routes of translocation of pigs and chicken across Mainland and Island Southeast Asia.

Source: P.J. Piper; Base Map: P. Bellwood, ANU Cartography. 
Storey et al. (2012) originally argued that Haplogroup E chickens were the first to arrive in the Pacific, and made connections between Polynesian explorers and pre-European origins of Haplogroup E chickens in South America. More recently, Thomson et al. (2014) found that the majority of modern and all ancient chickens in the Pacific were Haplogroup D, rather than the proposed E. Furthermore, and importantly, east of the Solomon Islands the only ancient D haplotype chickens recorded are those possessing a specific signature termed the 'Pacific or Polynesian motif' (Figure 15.2). West of the Pacific Islands, Thomson et al. (2014) only found this specific D haplotype in the Philippines. This, based on the current chicken genetic evidence, and the independent spread of the Pacific D chickens east of Vanuatu, suggests an initial arrival with human populations from the Philippines into Near Oceania.

\section{Dogs}

Most modern and ancient DNA studies investigating the origins and routes of translocations of the domestic dog in MSEA and ISEA have focused on the Australian dingo (Canis lupus dingo). This is because archaeological research has indicated dingoes probably represent the earliest translocation of canids across ISEA and introduction to the Australasian region. This interpretation is supported by the genetic evidence, which places these relatively ancient dog breeds at the base of phylogenetic trees (Larson et al. 2012).

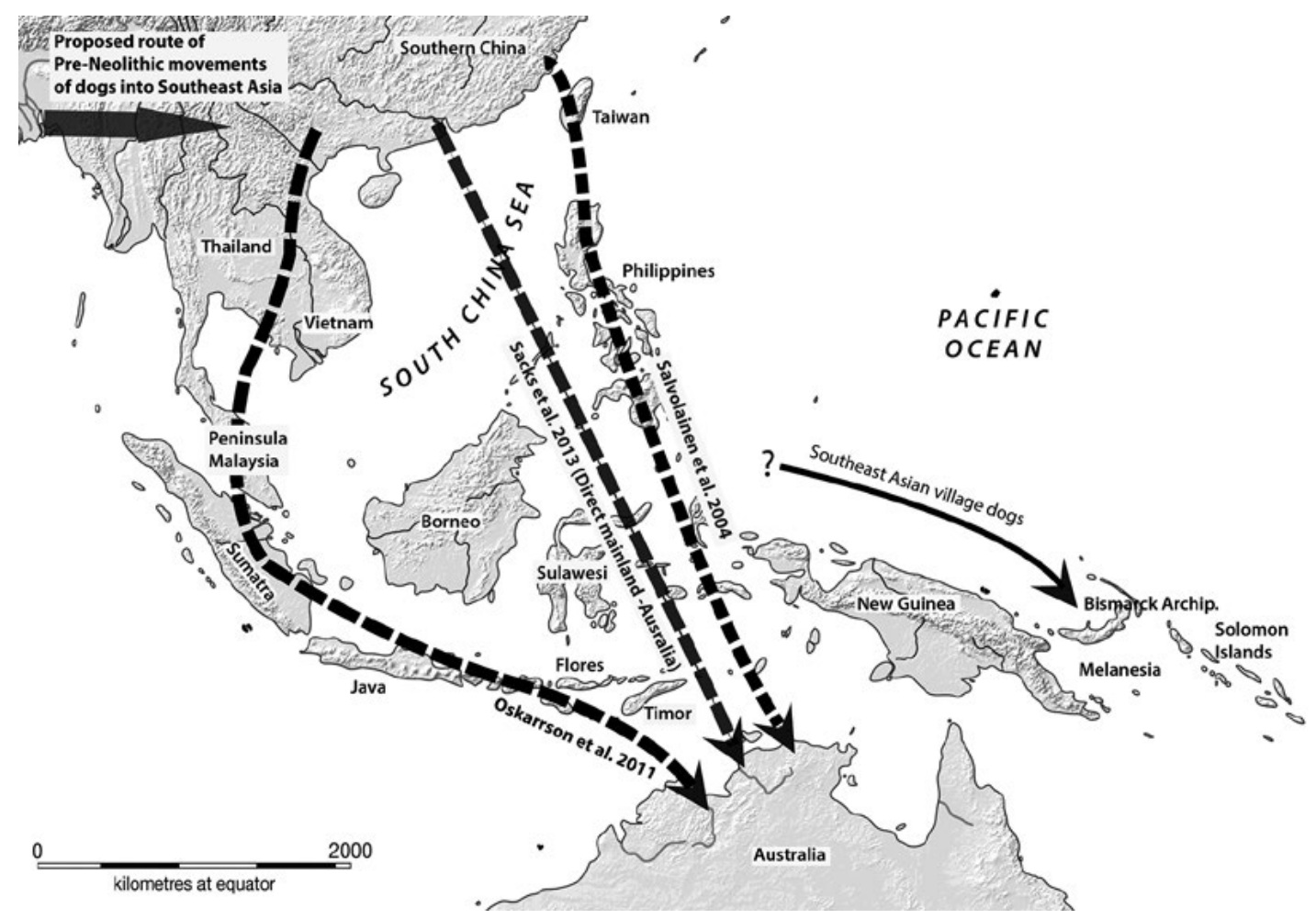

Figure 15.3 The proposed routes of translocation of dogs across Mainland and Island Southeast Asia.

Source: P.J. Piper; Base Map: P. Bellwood, ANU Cartography.

Salvolainen et al. (2004) analysed modern mtDNA from 211 dingoes, 38 Eurasian wolves and 676 dogs from all continents, as well as 19 pre-European archaeological dog samples from Polynesia. They identified a distinctive substitution (known as A29) in dingo mtDNA with a mean genetic distance that indicates an origin for the lineage at $c a .5000$ BP. They suggested that the dingo originated from domestic dogs in East Asia, and was transported across ISEA as part of the Austronesian expansion, after 4000 BP (Figure 15.3). However, Oskarsson et 
al. (2011) argued that there was no evidence for the A29 substitution in any of the modern Taiwanese and Philippine dog samples they studied, and an Austronesian introduction of the dog to Polynesia was unlikely. Instead they proposed a southern Chinese origin for the dingo lineage, and a route of translocation through Southeast Asia and Indonesia, not that dissimilar to the proposed route for the Pacific Clade of pigs (Figure 15.3; see Larson et al. 2007). Other studies have also suggested a southern Chinese/MSEA origin for domestic dogs (Ding et al. 2012; Pang et al. 2009).

Sacks et al. (2013) propose a more complicated scenario, whereby the first dogs introduced into MSEA possibly came from the west, in South Asia (though no point of origin is specified) in the pre-Neolithic, and these were later replaced throughout MSEA during the expansion of farming communities across the region (Figure 15.3). Their study supports the hypothesis that ISEA dogs have their origins in MSEA, and that, contra to Oskarsson et al. (2011), Philippine dogs share their ancestry with those from Indonesia. Dingoes are also more likely to originate from the Mainland than Taiwan (though the latter location cannot be entirely discounted), but a unique haplotype, derived from (H5) observed in dingoes, but not in other ISEA modern dog populations, argues against their close relationship. Thus, Sacks et al. (2013) have proposed a direct translocation from MSEA/Taiwan of the dingo to Australia, with mutations indicating a common ancestor between the two populations at $c a$. 5000-4000 BP (Figure 15.3).

Freedman et al. (2014) also argued for a pre-agricultural origin and translocation of the dingo from the Mainland to Australia. This was primarily based on the fact that dingoes only have two copies of the starch digestion gene, and this probably meant that they were unlikely to have had any close association with cultivators of cereal crops.

One modern human genetic study has argued for considerable gene flow between Indian and Australian Aboriginal populations some 4,200 years ago, and that this coincided with introduction of the dingo and microlithic blade technologies to Australia (Pugach et al. 2013). Gollan $(1980,1984)$ made the same argument for an ancient connection between Indian and Australian populations based on the sudden appearance of backed blades and his morphometric study of dingo and Indian pariah dog crania.

\section{Zooarchaeological evidence for pigs, dogs and chickens}

The purported occurrence of domestic dogs in the bone assemblages of forager communities in the Yongjiang Valley in Guangxi around 7000 BP and in Dingsishan sites at 6500-5000 BP is significant in that it suggests that dogs were potentially present in southern China prior to the arrival of agriculturalists (Zhang and Hung 2010). However, close examination of the zooarchaeological data from Dingshishan indicates that dogs were only identified in the upper horizons of the site in association with rice agriculture ( $\mathrm{Lu} 2010)$, and thus likely a later introduction than previously reported. Pigs have been described from the later layers at Tanshishan phase sites in Fujian on the southeast coast of China, opposite Taiwan, dating to $c a$. 5000-4300 BP and associated with agriculture (Hung and Carson 2014), and could have been introduced to Southeast Asia with the earliest farming communities. As far as the author is aware there are no reports of domestic chicken remains from southern China in the Neolithic as yet. 


\section{Mainland Southeast Asia}

Bui Vinh (1991) has claimed the presence of domestic dogs at the late forager site of Con Co Ngua, and Patte (1932) also reported a 'dog' ulna similar in size to that of the dingo from the site of Da But, both in Thanh Hoa Province of northern Vietnam and dating to $c a$. 5500-6500 BP. Both these claims are yet to be corroborated and the specimens clearly distinguished from native wild canids.

Dogs and domesticated pigs have, however, been identified in northern Vietnam, at the transitional forager-farmer site of Man Bac dating from ca. 3700-3500 cal. BP onwards (Matsumura and Oxenham 2011; Sawada et al. 2011). Canid remains morphologically similar to modern domestic Vietnamese dogs were reported from Dong Dau in the earliest levels of Phung Nguyen cultural deposits dated to 3328 \pm 100 uncal. BP; Gollan 1980: 222). In the Mekong Delta region of southern Vietnam, dogs and pigs are present at the agricultural settlement sites of An Son (4000-3500 cal. BP) (Piper et al. 2014) and Loc Giang dating to $c a$.3800-3300 cal. BP onwards (Piper et al. in press), and at Rach Nui from 3500 cal. BP onwards (Oxenham et al. 2015; Piper and Oxenham 2014). There is also a tentative identification of a chicken tarsometatarsus from a securely stratified layer at Loc Giang dating to $c a .3500 \mathrm{cal}$. BP (Piper et al. in press).

Domestic animals are absent from the hunter-gatherer site of Nong Nor in central Thailand, occupied around 4300 BP (Higham 2004), but dogs are present at the proposed forager site of Kok Phanom Di (KPD) after ca. 3700 cal. BP. Higham (2004) and Kijngam (2011) have argued that the appearance of dogs at KPD coincides with movements of rice agriculturalists into the region who brought dogs with them. There are also records of dog, pigs (possibly domesticated) and chickens from Non Nok Tha (Higham 1975) from 3400-3100 cal. BP (Higham et al. 2014), pigs and dogs from Ban Chiang (Higham et al. 1980) from 3600 BP (Higham et al. 2011), and chickens at Ban Na Di (Storey et al. 2012). In the earliest phases of Ban Non Wat, dating to 3650-3250 cal. BP, the dogs are considered to be from domestic stock, the chickens were possibly domesticated and the pigs await aDNA and geometric morphometric determinations (Higham and Higham 2008; Kijngam 2011).

\section{Island Southeast Asia}

Source populations of domestic pigs and dogs for introduction to ISEA appear to have been present across parts of MSEA from at least $4000 \mathrm{BP}$ onwards, and dogs have been recorded at Nanguanli in Taiwan dating from $c a .4800 \mathrm{BP}$ (Tsang et al. 2006). The prehistoric status of pigs in Taiwan remains unclear but there is a strong possibility they were present from at least $c a$. $4000 \mathrm{BP}$.

In the Philippines a direct $\mathrm{C}^{14}$ determination on a pig lower fourth premolar from Nagsabaran in northern Luzon produced a date of 3940 440 BP (WK-23397) or 4499-4332 (77.4 per cent) 14568-4520 (13.2 per cent) cal. BP (all radiocarbon dates herein recalibrated using OxCal 4.2, IntCal 13; Bronk Ramsey 2015). This currently represents the earliest evidence for the introduction of domestic pigs into ISEA (Piper et al. 2009). There is no dog recorded in the early phases of Nagsabaran so far, but a dog burial at the base of the shell midden probably dates to between 2800-2500 BP (Amano et al. 2013; Piper et al. 2009). A canid 3rd left metatarsal found in Callao Cave in the Peñablanca region of northern Luzon is loosely associated with a radiocarbon date from the same stratigraphic unit of $3335 \pm 34$ or $3650-3470$ cal. BP (WK17010; Mijares 2006: 39; Piper et al. 2013). There is no evidence of wild canids ever inhabiting the Philippine archipelago east of Palawan and this is almost certainly from a domestic dog. Supporting evidence for a possible mid-third millennium BC introduction of dogs to the Philippines also comes from Pasimbahan Cave on Palawan where a dog occipital fragment was 
recovered from a deposit with an associated radiocarbon date on charcoal of $3401 \pm 26$ or $3753-$ 3628 cal. BP (WK34844; Ochoa et al. 2014). The 'early' age determinations on associated pieces of charcoal from both Callao and Pasimbahan should be regarded with caution. At Savidug Dune Site on Sabtang in the Batanes Islands, between Taiwan and Luzon, pig is present from ca. 3100 cal. BP, but dogs are first recorded only in association with dates of 2500-2300 cal. BP. A single right tibiotarsus fragment from Savidug Dune site dating to ca. 2500-2300 cal. BP has been tentatively identified as domestic fowl (Bellwood and Dizon 2013; Piper et al. 2013).

Geometric-morphometric studies of archaeological pig teeth from Niah Cave on Borneo were inconclusive, but indicated that it was unlikely that any of the pig remains recovered within sequences securely dated to the earliest pottery phases before $c a .3500 \mathrm{BP}$ were domestic (Cucchi et al. 2009). A few pig teeth from a single individual with domestic affinities were found at Lobang Magala E, and were considered to be of 'Neolithic' age by Medway (1973). However, the provenance of this specimen is insecure and it is highly likely to be post-Neolithic (Lloyd-Smith et al. 2013). Domestic pigs and dogs are certainly present at Niah by the early Metal Age from ca. 2500 BP onwards (Szabó et al. 2013).

There are two early enigmatic records of canids in ISEA. A single canine and calcaneus in the Agop Sarapad entrance to Madai Cave in Sabah (MAD2), north Borneo, are dated by freshwater shell to $c a$. 10,000-9000 BP (Bellwood 1988: 125; Cranbrook 1988a: 147, 1988b) and four bones within secure contexts date to the Terminal Pleistocene and early Holocene (10,000 BP and older) from Ille Cave, northern Palawan (Lewis et al. 2008; Piper et al. 2011). None of these remains are diagnostic enough to distinguish between Canis and Cuon alpinus (Asiatic wild dog). Cranbrook (2014) proposes that the early canid remains from Borneo and Palawan could represent remains of early domestic dogs introduced to the islands long before the Austronesian diaspora. However, both Borneo and Palawan were conjoined to the mainland during the Middle and/or Late Pleistocene (Robles et al. 2015) and the most parsimonious explanation for the presence of these canid remains at such early dates in ISEA is that they represent locally extinct populations of the Asiatic wild dog that had reached the islands across land-bridges during periods of low sea stand (Cranbrook 1988; Piper et al. 2011).

The only domestic animal reported from Indonesia west of Wallace's Line dating to greater than $2500 \mathrm{BP}$ is a partial skeleton of a dog from Hoekgrot on the south coast of East Java. Storm (2001: 31) reports that this specimen had uncertain associations with two dates of $2655 \pm 60$ or $2925-2544$ cal. BP on 'fauna' and $3265 \pm 55$ BP or 3630-3381 cal. BP on human bone (no lab codes provided).

On Sulawesi, Minanga Sipakko and Kamassi in the Kalumpang region of the Karama River Valley produced pigs, probably of domestic origin. These were recorded in some of the oldest archaeological deposits at around 3500 BP, or slightly earlier in Minanga Sipakko (Anggraeni et al. 2014). Indirect evidence for the presence of dogs at Kamassi was recorded in the form of bone gnawing and digestion from the earliest phases of occupation, but actual dog bones are only present from $c a$. $3000 \mathrm{BP}$ onwards.

Glover (1986) had argued for a date as early as 5000-4000 BP for the East Timor dog remains studied by Gollan (1980). However, his East Timor chronology, which relied on extrapolation from a small number of available dates, is no longer considered reliable. A single pig tooth from Uai Bobo 2 Horizon VII, recovered from deposits dating to $c a .5600$ BP (Glover 1986: 204), is also considered unreliable. The earliest securely dated canid remains in East Timor come from a dog burial in Matja Kuru 2 (Gonzalez et al. 2013; Veth et al. 2005). Two direct radiocarbon assays obtained on bones from the skeleton returned dates of $2967 \pm 58$ or 3335-2961 cal. BP 
(95.4 per cent; Wk-10051) and $2867 \pm 26$ BP or 3070-2885 cal. BP (95.4 per cent; Wk-34931) (3138-2929 cal. BP, 95.4 per cent probability, $\mathrm{X}^{2}$ test: df-1, T-2.5 (5 per cent; 3.8)) indicating the presence of dogs on the island at the end of the second millennium BC (Veth et al. 2005).

Pig bones identified as the Pacific Clade haplogroup of S. scrofa have been recovered from Liang Bua Cave on Flores in deposits dating to after $4000 \mathrm{BP}$, and in association with pottery and other evidence of Neolithic material culture. However, a suid tooth from the same site identified through aDNA as Sulawesi warty pig (S. celebensis) was recovered in association with a charcoal sample dated to $c a .7000 \mathrm{BP}$ (Larson et al. 2007). The dog was only recorded in sub-surface layers at Liang Bua dating to within the last 500 years (van den Bergh et al. 2009). Although Meijer et al. (2013) conducted comprehensive studies on the avifauna from Liang Bua there is no mention of domestic chicken.

Numerous excavations in the Moluccas during the early 1990s produced evidence of early domesticates only from the site of Uattamdi on Kayoa Island, in association with red-slipped pottery. The earliest pig bones were recovered in layers dating between two radiocarbon dates of $3260 \pm 70$ or $3693-3409$ cal. BP (ANU-9323) and $2610 \pm 170$ or 3211-2375 cal. BP (ANU7775). The initial appearance of dog was recorded in slightly later deposits between 3211-2375 cal. BP and 2330 \pm 70 or 2590-2202 cal. BP (ANU-9322; Bellwood et al. 1998; Bellwood and White 2005; Flannery et al. 1998).

In the Banda group of islands, pig is recorded at the site PA1, on Ay Island, in association with a fragment of red-slipped pottery similarly incised to Lapita pottery and dated to $3150 \mathrm{BP}$ (Lape 2000).

\section{Oceania (with relevance to initial introduction from Southeast Asia)}

The earliest evidence for the introduction of pig and chicken to Near Oceania is associated with the initial developments of the Lapita Cultural Complex, recently re-dated to between 33503300 BP (Summerhayes 2007; Kirch 2010). For example, a few pig and chicken bones have been identified in early Lapita contexts from Talepakemalai (Gosden et al. 1989; Matisoo-Smith 2007), and chicken is recorded at Etakosarai on Mussau (Matisoo-Smith 2007), and from Kainapirina on Watom the earliest reliable dates for pig is 2760-2547 cal. BP (Hawkins 2015). Direct dates on pig and chicken bones from Teouma in Vanuatu are calibrated to between ca. 3100-2700 cal. BP, indicating that both these domestics were introduced during the earliest phases of site occupation (Petchey et al. 2015). It is interesting to note that amongst the thousands of animal bones studied by Hawkins (2015), which included substantial records of pig and chicken, there was not a single dog bone. Chicken bones have also been recovered from Mdailu in the southeast Solomons in association with Lapita pottery, dating to after 3200 BP (McCoy and Cleghorn 1988; Storey et al. 2012). Pigs and chickens have been identified on Reef Santa Cruz (RF2) dating between 3200-2800 BP, and sporadic reports of pig and dog bones have also been published from sites such as Apalo in the Arawe Islands (Gosden et al. 1989) and Balbalankin (pig only; 2950-2360 cal. BP) in the Anir Islands, and pigs at Lebang Halika on Nissan from 3300 BP onwards (Matisoo-Smith 2007). Kirch (1987) originally reported dog from Talepakemalai on Mussau but the identification has been questioned by Matisoo-Smith (2007), and from Tikopia (TK-4) dated to $c a$. 2800 BP (Matisoo-Smith 2007). Probably the earliest reliable dates for dog in Lapita are from Kamgot (3380-2950 cal. BP) where Summerhayes (personal communication, 2016) reports five definite dog bones from the earliest levels of the site. Although, Anderson (2009) suggests that dogs are absent from early Lapita, it seems that they were perhaps present on a few sites in Near Oceania. However, as noted for Teouma on Vanuatu, dogs do not appear to have reached Remote Oceania as early as pigs and chickens. 


\section{Australia}

The arrival of the dingo into Australia is still very poorly understood. The two earliest fairly reliable dates (though it is suggested that even these 1960s dates be treated with caution) for dogs in Australia are 3450 \pm 95 (ANU-850) or 3981-3528 cal. BP from Madura cave in Western Australia (Milham and Thompson 1976), and at Fromm's Landing in South Australia where a dingo skeleton was recovered from deposits between two dates on charcoal of $3220 \pm 94$ (NPL-29) or 3695-3267 cal. BP and 3000 \pm 91 (NPL-28) or 3443-2978 cal. BP (Macintosh 1964). Gollan (1984: 926) places the entry of dog to Australia at $c a$. 4200-4000 BP, and a date of between $5,000-3,000$ years ago is generally accepted for the arrival of the ancestor of the Australian dingo (Crowther et al. 2014).

\section{Discussion}

\section{Mainland Southeast Asia}

There is currently no solid evidence for an association between domestic animals and huntergatherers in MSEA. Domestic pigs and dogs are present in the earliest phases of Phung Nguyen Culture of northern Vietnam at $c a .4000 \mathrm{cal}$. BP or slightly earlier as human populations apparently spread southwards from the provinces of Fujian-Guangdong and/or Guangxi into MSEA (Zhang and Hung 2008, 2010). Both pigs and dogs are present in early phases of settlement development in northern and southern Vietnam along the Red and Vam Co Dong Rivers, respectively, by $c a$. 4000 BP (Piper and Oxenham 2014; Piper et al. 2014). This distribution of domestic pigs and dogs corresponds well with the proposed origins and expansion of the Pacific Clade pigs, from southern China across parts of MSEA, likely associated with the movements of Austroasiaticspeaking populations. Domestic dogs, and possibly managed pig populations, are also present in the earliest rice agricultural settlements of Ban Non Wat, Ban Chiang and Non No Tha in northern and central Thailand. But the absence of the Pacific Clade of pigs from Thailand and Cambodia perhaps implies different origins for domestic pigs in east and west MSEA.

That east and west MSEA were on slightly different domestication trajectories is also apparent in the initial appearance of domestic cattle (Bos sp.) across the region. In Thailand, cattle have been recorded at Non Nok Tha by ca. 3500 BP (Higham and Leach 1971; Higham et al. 2014) and Ban Non Wat (Kijngam 2011) from at least ca. 3600 BP onwards. In northern and southern Vietnam, evidence of domestic bovines is completely absent from Neolithic sites (Sawada et al. 2011; Piper et al. 2014). The potential use of domestic cattle as traction animals for ploughs in the Neolithic of Thailand, and their absence in Vietnam, has implications for the differential timing of agricultural intensification across the region.

Bird identifications in the archaeological record are still rare across MSEA (as they are in ISEA) due to a lack of specialist study, and poor bone preservation. Thus, it is still difficult to assess the distribution of fowl across the region. However, in northern and central Thailand, a region within the natural biogeographic distribution of wild red jungle fowl (Gallus gallus), and where early domestication has been proposed (Fumihito et al. 1996), chicken bones are relatively common in early Neolithic sites, from $c a .3700$ BP onwards. The deliberate inclusion of fowl in burials at sites such as Non Nok Tha and Ban Na Di (Storey et al. 2012) indicates a close relationship between domesticated chickens and people. The evidence for chicken domestication to the east is more equivocal. In southern Vietnam where domestic pigs and dogs have been reported, chickens appear to be almost completely absent from the archaeological record. A single tibiotarsus dating 
to $c a .3500 \mathrm{cal}$. BP from the settlement site of Loc Giang has been interpreted as a possible small domestic fowl. This raises the possibility that chickens were domesticated in, or introduced to, west MSEA prior to their spread south and east across the region.

Neolithic domestic animals remain unreported in the Thai-Malay Peninsula before 3000 BP, but this geographic locale is likely to be where Pacific Clade pigs passed through en route to the Pacific (see below).

\section{Island Southeast Asia}

It has been argued that the translocation of the Sulawesi warty pig from Sulawesi to surrounding islands could reflect the earliest domestication event in ISEA (van den Bergh et al. 2009). However, the early mid-Holocene timing for warty pig movements is based on a single insecure associated radiocarbon date on charcoal of $7000 \mathrm{BP}$ from Liang Bua, Flores. As has been recently demonstrated with the purported early pig introduction into New Guinea (O'Connor et al. 2011), there is a possibility that the date for warty pig translocation will turn out to be considerably younger than originally reported. The enigmatic early Holocene records of a canid in Borneo and Palawan could potentially represent early introductions of domestic dogs to the region (see Cranbrook 2014). But as both islands are located within the Sundaic biogeographic region and were connected to the mainland during different periods of the Pleistocene, they could just as easily represent extinct populations of the Asiatic wild dog (Cuon alpinus), which is still present in Sumatra and Java. Future recovery of diagnostic anatomical elements, and/or aDNA would help resolve this issue.

Thus, on present evidence the earliest securely dated introductions of domestic animals into ISEA all date to after 4500-4200 BP.

Interestingly, Bellwood (1997: 237) considered that the ca. 4000 BP material culture recovered from Gua Sireh in Sarawak, Malaysian Borneo, had more in common with the Peninsular Malaysian and southern Thai Neolithic than that identified to the east in the Philippines. This correlated neatly with Adelaar's (1995) argument for an Austroasiatic substratum in Land Dayak languages of western Sarawak, and indicated a possible migration from MSEA via Peninsula Malaysia into ISEA. Recent excavations at Takongen, Silabe and Harimau caves in Sumatra support a possible Austroasiatic movement into ISEA (Simanjuntak, Chapter 11, this volume), and this might have resulted in the introduction, and then human or down-the-line movement of pigs, dogs and chickens east, where they spread out to encompass most of ISEA, with the exception of the Philippine archipelago. Unfortunately, there is currently no zooarchaeological evidence reported for any of the 'big three' in Indonesia west of Wallace's Line, prior to ca. 2500 BP (except the poorly dated Hoekgrot dog) in support of the Thai-Malay Peninsula route of translocation. This is a result of limited zooarchaeological study and problems in differentiating domestic from wild pigs, and chickens amongst the Phasianidae in this diverse faunal region. However, the Pacific Clade pig has been identified in ca. 4000 BP deposits in Liang Bua Cave, Flores, and at Uattamdi, Kayoa Island, at $c a .3200 \mathrm{cal}$. BP, indicating prehistoric movements through the region (though direct bone dates would be useful). The Pacific Clade of pigs was introduced to Near Oceania, perhaps during the early phases of Lapita development in the Bismarck archipelago at $c a$.3300-3200 cal. BP, and then onwards to Vanuatu.

Based on genetic and (some) zooarchaeological evidence a second, though more enigmatic, introduction of domestic pigs, chickens and perhaps dogs occurred in the Philippines during the late third or early second millennium BC. Domestic pigs, possibly of the Lanyu haplotype, appear to have been introduced to the Batanes Islands by at least $3200 \mathrm{BP}$, and were also present in the 'open air' site of Nagsabaran in the Cagayan Valley by around $c a .4000$ cal. BP (Piper et al. 2009, 2013). This suggests introduction during or shortly after the initial establishment of the earliest 
sedentary settlements associated with colonisation by Austronesian-speaking populations in the Philippines (see Hung and Carson 2015). Dogs were potentially present in the Philippines from ca. $4000 \mathrm{BP}$ onwards but this still needs to be confirmed by more securely stratified specimens, or preferably, direct radiocarbon dates on dog bone. The physical remains of chickens are still absent from the archaeological record, but the unique Pacific D (Polynesian) haplotype with its possible origins in the Philippines suggests considerable antiquity for domestic fowl in the archipelago. This is supported by the identification of the Pacific D motif in chickens dated to ca. 3100-2700 cal. BP on Vanuatu (Petchey et al. 2015). A Philippine rather than Taiwan origin for the chicken also fits with the linguistic evidence in that there is no known Proto-Austronesian (Formosan) terms for domestic fowl, but they do occur in Proto-Malayo-Polynesian (Blust 1995). The absence of the Polynesian motif through eastern Indonesia suggests a possible direct introduction from the Philippines to the Solomon Islands and Vanuatu (though the aDNA research is still very limited). Furthermore, this haplotype of chickens is the only one translocated beyond Vanuatu into Remote Oceania. The presence of chickens with the 'Polynesian motif' on Vanuatu in association with the Pacific Clade of pigs from Indonesia implies staggered arrival times in Near Oceania (see also Anderson 2009).

In Sulawesi, provisional morphometric analyses of pig teeth from the deepest and oldest layers at the sites of Kamassi (Kamansi) and Minanga Sipakko in the Karama Valley suggest introduction during or shortly after the establishment of these, the oldest known 'open air' settlement sites on the island. Dog remains are absent from the earliest deposits. These settlements have been interpreted as representing those constructed by initial colonisers migrating southwards from the Philippines (Anggraeni et al. 2014). Future genetic and morphometric analyses will hopefully link the ancient domestic animal introductions either with Philippine or Indonesian lineages.

Currently, the earliest evidence for domestic dogs in ISEA is the $c a .3000-2800$ cal. BP skeletal remains from East Timor and the early to mid-first millennium BC canid bones from Uattamdi. Biometric analysis of the well-preserved Timor dog indicates a similar stature to other prehistoric and contemporary village dogs across ISEA and the Pacific (Gonzalez et al. 2013). The village dogs' of eastern Indonesia and the Pacific appear to be morphologically unrelated to Australian dingoes and perhaps represent an entirely different dog introduction to ISEA, as has also been suggested through genetic analysis by Sacks et al. (2013) and Shannon et al. (2015). Thus, the zooarchaeological and genetic evidence suggests at least two different dog translocations into ISEA before 3000 BP, with dingoes reaching Australia and Southeast Asian village dogs being transported into the Pacific. The possible absence of dogs in early settlement sites in the Solomons and on Vanuatu suggests they were a later arrival in Remote Oceania than pigs and chickens.

Recently, Fillios and Taçon (2016) have argued that the dingo could have been transported first to Sulawesi and then onwards to Australia sometime prior to the arrival of Austronesian migrants, by members of the Toalean forager culture. Although the absence of evidence for pottery and other material culture associated with the Neolithic in Australia and the lack of cereal digestion genes in dingoes could indicate a pre-Neolithic movement, there is currently a lack of archaeological remains of domestic dogs anywhere in MSEA and ISEA before $4500 \mathrm{BP}$, or of a pre-3000 BP date in Sulawesi to support this hypothesis. The origins of routes of translocation across ISEA of both dog lineages proposed here currently remain unknown. 


\section{Conclusion}

When Peter Bellwood initially proposed more than three decades ago that the 'big three' were first introduced to, and spread across, MSEA and ISEA by Austroasiatic- and Austronesianspeaking agriculturalists, with their ultimate origins in China, he could not have envisaged how complicated the unraveling story of animal domestication and translocation across the region would become.

Based on current evidence, none of the 'big three' was domesticated in or introduced to MSEA and ISEA prior to $c a .4500 \mathrm{BP}$. Thereafter, multiple translocation events probably resulted in two or more lineages of pigs, dogs and chickens originating in, or entering, MSEA and ISEA from the northeast and west. The appearance and spread of domestic pigs and dogs in early sedentary settlement sites across Vietnam supports the farming/language hypothesis and the spread of Austroasiatic-speaking agriculturalists from southern China through much of eastern MSEA. But genetic and zooarchaeological evidence also indicates a South Asian or Thailand origin for domestic chickens, and suggests a succeeding spread of fowl south and east into the Thai-Malay Peninsula and possibly Vietnam. Pigs, dogs and chickens found in ISEA all have their origins on the mainland.

Referring to comments by Pawley and Green (1975), and based on linguistic reconstructions, Bellwood wrote of the Proto-Austronesian (PAN) speakers of Taiwan: 'they kept pigs, and probably dogs and chickens, and made pottery' (Bellwood 1979: 122). Undoubtedly, the early forager-farmers of Taiwan were acquainted with pigs and dogs, with the chicken evidence remaining enigmatic. However, of the pig, dog and chicken genetic lineages with which the Proto-Austronesian and/or early Malayo-Polynesian speakers (in the Philippines) were familiar, only the chicken appears to have spread more widely, reaching Remote Oceania. The presence of both the 'Polynesian motif' chickens and Pacific Clade pigs in Near Oceania/Solomon Islands and Vanuatu suggests multiple, staggered introductions of domestic animals of different origins into Oceania. The presence of pigs in early archaeological sites in Remote Oceania suggests that suids along with chickens were transported early with the initial colonists. This argument is supported by lexical evidence that the first Oceanic speakers in Remote Oceania practised pig husbandry (see Pawley, Chapter 17, this volume). Interestingly, Valentin et al. (2015) identified the origins of the Lapita populations of Teouma on Vanuatu as Southeast Asian, and ultimately of East Asian descent. They also observed heterogeneity in the cranial morphometrics of the individuals studied and interpreted this as potentially reflecting diversity in their geographic origins. This would fit neatly with the variation observed in the likely sources of the domestic animals arriving in Oceania.

At least two lineages of dogs were apparently introduced to ISEA, the dingo and village dog, whose origins and routes of translocation across the region remain unknown. There is still a possibility that the dingo was transported across MSEA and ISEA prior to the movements of Austroasiatic- and Austronesian-speaking populations, and this would explain its unique and solo arrival in Australia. The Southeast Asian village dog was introduced more recently and was transported out into the Pacific. The lack of concrete evidence for dogs in early Lapita sites, certainly on the most westerly of the Remote Oceanic islands, suggests an introduction succeeding both pigs and chickens. 


\section{Acknowledgements}

The author would like to thank all those who have helped in the zooarchaeological analysis of numerous bone assemblages and tens of thousands of bones over the last 10 years. Many thanks also to Glenn R. Summerhayes for providing up to date information on the Kamgot Lapita fauna.

This research was funded by an ARC Future Fellowship grant to the author FT100100527.

\section{References}

Adelaar, K.A. 1995. Borneo as a cross-roads for comparative Austronesian linguistics. In P. Bellwood, J.J. Fox and D. Tryon (eds), The Austronesians: Historical and Comparative Perspectives, pp. 75-95. Canberra: The Australian National University.

Amano, Jr N., P.J. Piper, H.-c. Hung and P. Bellwood. 2013. Introduced domestic animals in the Neolithic and Metal Age of the Philippines: evidence from Nagsabaran, Northern Luzon. Journal of Island and Coastal Archaeology 8: 317-335. doi.org/10.1080/15564894.2013.781084.

Anderson, A. 2009. The rat and the octopus: Initial human colonization and the prehistoric introduction of domestic animals to Oceania. Biological Invasions 11: 1505-1519. doi.org/10.1007/s10530-0089403-2.

Anggraeni, T. Simanjuntak, P. Bellwood and P.J. Piper. 2014. New Research on the Karama Valley sites, West Sulawesi, Indonesia. Antiquity 88(341): 740-756. doi.org/10.1017/S0003598X00050663.

Bellwood, P. 1975. The prehistory of Oceania. Current Anthropology 16(1): 9-17. doi. org/10.1086/201515.

- 1976. Prehistoric plant and animal domestication in Austronesia. In G. de, G. Sieveking, I.H. Longworth and K.E. Wilson (eds), Problems in Economic and Social Archaeology, pp. 153-168. London: Duckworth.

1984. Archaeological research in the MadaiBaturong region, Sabah. Bulletin of the Indo-Pacific Prehistory Association 5: 38-56.

1988. The Madai excavations: Sites MAD 1, MAD 2 and MAD 3. In P. Bellwood (ed.), Archaeological Research in South-Eastern Sabah. Sabah Museum Monograph vol. 2, pp. 97-128. Kota Kinabalu: Sabah Museum and State Archives.

1996. Phylogeny vs reticulation in prehistory. Antiquity 70: 881-890. doi.org/10.1017/ S0003598X00084131.

—. 1997. Prehistory of the Indo-Malayan Archipelago. Hawai'i: University of Hawaii Press.

- 2001. Early agriculturalist population diasporas? Farming, languages and genes. Annual Review of Anthropology 30: 181-207. doi.org/10.1146/annurev.anthro.30.1.181.

—. 2005. First Farmers: The Origins of Agricultural Societies. Oxford: Blackwell.

—. 2013. First Migrants: Ancient Migration in Global Perspective. Chichester: Wiley-Blackwell.

Bellwood, P. and E. Dizon. 2005. The Batanes Archaeological Project and the 'Out of Taiwan' hypothesis for Austronesian dispersal. Journal of Austronesian Studies 1(1): 1-32.

Bellwood, P. and E. Dizon. 2013. The chronology of Batanes prehistory. In P. Bellwood, and E. Dizon (eds), 4000 Years of Migration and Cultural Exchange: Archaeology in the Batanes Islands, Northern Philippines, pp. 67-76. Terra Australis 40. Canberra: ANU E Press. 
Bellwood, P. and P. White. 2005. Domesticated pigs in Eastern Indonesia. Science 309: 381. doi. org/10.1126/science.309.5733.381a.

Bellwood, P., G. Nitihaminoto, G. Irwin, A. Gunadi, Waluyo and D. Tanudirjo. 1998. 35,000 years of prehistory in the northern Moluccas. In G.J. Bartstra (ed.), Bird's Head approaches: Irian Jaya studies, a program of interdisciplinary research. Modern Quaternary Research in Southeast Asia 15: $233-275$.

Bellwood, P., M. Oxenham, C.H. Bui, T.D.K. Nguyen, A. Willis, C. Sarjeant, P.J. Piper, H. Matsumura, K. Tanaka, N. Beavan, T. Higham, Q.M. Nguyen, N.K. Dang, K.T.K. Nguyen, T.H. Vo, N.B. Van, T.K.Q. Tran, P.T. Nguyen, F. Campos, Y-I Sato, L.C. Nguyen and N. Amano. 2011. An Son and the Neolithic of Southern Vietnam. Asian Perspectives 50 (1\&2): 144-174. doi.org/10.1353/ asi.2011.0007.

Blust, R.A. 1995. The prehistory of the Austronesian-speaking peoples: A view from language. Journal of World Prehistory 9(4): 453-510. doi.org/10.1007/BF02221119.

Bronk Ramsey, C. 2015. Oxcal 4.2 manual. c14.arch.ox.ac.uk/oxcal.html.

Bui, V. 1991. The Da But Culture in the Stone Age of Vietnam. Bulletin of the Indo-Pacific Prehistory Association 10: 127-131.

Bulmer, S. 1966. Pig bone from two archaeological sites in the New Guinea Highlands. Journal of the Polynesian Society 75(4): 504-505.

1975. Settlement and economy in prehistoric Papua New Guinea. Journal de la Sociétés des Océanistes 31(46): 7-75. doi.org/10.3406/jso.1975.2688.

- 1982. Human ecology and cultural variation in prehistoric New Guinea. In J. Gresswit (ed.), Biogeography and Ecology of New Guinea, pp. 169-206. The Hague, Netherlands: DR Junk. doi. org/10.1007/978-94-009-8632-9_8.

Cranbrook, E.-O. 1988a. Report on bones from the Madai and Baturong cave excavations. In P. Bellwood (ed.), Archaeological Research in South-Eastern Sabah. Sabah Museum Monograph vol. 2, pp. 142-154. Kota Kinabalu: Sabah Museum and State Archives.

- 1988b. The contribution of archaeology to the zoogeography of Borneo, with the first record of a wild canid of early Holocene age. Fieldiana Zoology 42: 1-7.

- 2014. Archaeology of the dog in Borneo: New evidence from the Everett Collection in the Natural History Museum, London. In K. Boyle, R. Rabett and C. Hunt (eds), Living in the Landscape: Essays in Honour of Graeme Barker, pp. 171-182. McDonald Institute Monographs. Cambridge: McDonald Institute for Archaeological Research.

Crowther M.S., M. Filios, N. Colman and M. Letnic. 2014. An updated description of the Australian dingo (Canis dingo Meyer, 1793). Journal of Zoology (1987) 293: 192-203. doi.org/10.1111/ jzo. 12134 .

Cucchi, T., M. Fujita and K. Dobney. 2009. New insights into pig taxonomy, domestication and human dispersal in Island South East Asia: Molar shape analysis of Sus remains from Niah Caves, Sarawak. International Journal of Osteoarchaeology 19(4): 508-530. doi.org/10.1002/oa.974.

Cucchi, T., A. Hulme-Beaman, J. Yuan and K. Dobney. 2011. Early Neolithic pig domestication at Jiahu, Henan Province, China: Clues from molar shape analyses using geometric morphometric approaches. Journal of Archaeological Science 38: 11-22. doi.org/10.1016/j.jas.2010.07.024. 
Diamond, J. and P. Bellwood. 2003. Farmers and their languages: the first expansions. Science 300: 597-603. doi.org/10.1126/science.1078208.

Ding Z.-L., M. Oskarsson, A. Ardalan, H. Angleby, L-G. Dahlgren, C. Tepeli, E. Kirkness, P. Savolainen and Y-P. Zhang. 2012. Origins of domestic dog in southern East Asia is supported by analysis of Y-chromosome DNA. Heredity 108: 507-514. doi.org/10.1038/hdy.2011.114.

Fillios, M.A. and P.S.C. Taçon. 2016. Who let the dogs in? A review of the recent genetic evidence for the introduction of the dingo to Australia and implications for the movement of people. Journal of Archaeological Science 7: 782-792. doi.org/10.1016/j.jasrep.2016.03.001.

Flannery, T., P. Bellwood, J.P. White, T. Ennis, G. Irwin, K. Schubert and S. Balasubramanian. 1998. Mammals from Holocene archaeological deposits on Gebe and Morotai Islands, Northern Moluccas, Indonesia. Australian Mammalogy 20(3): 391-400.

Freedman, A.H., I. Gronau, R.M. Schweizer, D. Ortega-Del Vecchyo, E. Han, P.M. Silva, M. Galaverni, Z. Fan, P. Marx, B. Lorente-Galdos, H. Beale, O. Ramirez, F. Hormozdiari, C. Alkan, C. Vilà, K. Squire, E. Geffen, J. Kusak, A.R. Boyko, H.G. Parker, C. Lee, V. Tadigotla, A. Siepel, C.D. Bustamante, T.T. Harkins, S.F. Nelson, E.A. Ostrander, T. Marques-Bonet, R.K. Wayne and J. Novembre. 2014. Genome sequencing highlights the dynamic early history of dogs. PLoS Genetics 10(8): e1004631. doi.org/10.1371/journal.pgen.1004016.

Fumihito, A., T. Miyake, M. Takada, R. Shingu, T. Endo, T. Gojobori, N. Kondo and S. Ohno. 1996. Monophyletic origin and unique dispersal patterns of domestic fowls. Proceedings of the National Academy of Sciences 93: 6792-6795. doi.org/10.1073/pnas.93.13.6792.

Glover, I. 1986. Archaeology of Eastern Timor, 1966-67. Terra Australis 11. Canberra: Department of Prehistory, Research School of Pacific and Asian Studies, The Australian National University.

Gollan K. 1980. Prehistoric Dingo. Unpublished PhD thesis, The Australian National University, Canberra.

- 1984. The Australian dingo: In the shadow of man. In M. Archer and G. Clayton (eds), Vertebrate Zoogeography and Evolution in Australasia, pp. 921-927. Perth: Haesperton.

Gonzalez, A., G. Clark, S. O’Connor and L. Matisoo-Smith. 2013. A 3000 year old dog burial in Timor-Leste. Australian Archaeology 76: 13-29. doi.org/10.1080/03122417.2013.11681961.

Gosden, C., J. Allen, W. Ambrose, D. Anson, J. Golson, R. Green, P. Kirch, I. Lilley, J. Specht and M. Spriggs. 1989. The Lapita sites of the Bismarck Archipelago. Antiquity 63(240): 561-586. doi. org/10.1017/S0003598X00076559.

Groves, C. 1981. Ancestors for the Pigs: Taxonomy and Phylogeny of the Genus. Sus Technical Bulletin 3. Canberra: Department of Prehistory, Research School of Pacific Studies, The Australian National University.

- 2007. Current views on taxonomy and zoogeography of the genus Sus. In U. Albarella, K. Dobney, A. Ervynck and P. Rowly-Conwy (eds), Pigs and Humans: 10,000 Years of Interaction, pp. 15-29. Oxford: Oxford University Press.

Hawkins, S.C. 2015. Human Behavioural Ecology, Anthropogenic Impact and Subsistence Change at the Teouma Lapita Site, Central Vanuatu, 3000-2500 BP. Unpublished PhD thesis, The Australian National University, Canberra.

Herrera, M. 2010. An archaeogenetic study of the genus Sus in the Philippines and its propositions for understanding human translocation in Island Southeast Asia. Unpublished Master's thesis, University of the Philippines, Manila. 
Higham, C.F.W. 1975. Aspects of economy and ritual in prehistoric Northeast Thailand. Journal of Archaeological Science 2: 245-288. doi.org/10.1016/0305-4403(75)90001-1.

2004. Mainland Southeast Asia from the Neolithic to the Iron Age. In I. Glover and P. Bellwood (eds), Southeast Asia from Prehistory to History, pp. 41-67. London: Routledge.

- 2013. Summary and conclusions, In C.F.W. Higham and A. Kijngam (eds), The Origins of the Civilization of Angkor, vol. 4, The Excavation of Ban Non Wat: The Neolithic Occupation, pp. 199-211. Bangkok: The Thai Fine Arts Department.

2015. Southeast Asian Mainland: Archaeology. In P. Bellwood (ed.), The Global Prehistory of Human Migration, pp. 269-275 Chichester: Wiley-Blackwell.

Higham, C.F.W. and B.F. Leach. 1971. An early centre of bovine husbandry in Southeast Asia. Science 172(3978): 54-56. doi.org/10.1126/science.172.3978.54.

Higham, C. and T. Higham. 2008. A new chronological framework for prehistoric Southeast Asia, based on a Bayesian model from Ban Non Wat. Antiquity 83: 125-145. doi.org/10.1017/ S0003598X00098136.

Higham, C., T. Higham and A. Kijngam. 2011. Cutting a Gordian Knot: the Bronze Age of Southeast Asia: origins, timing and impact. Antiquity 85: 583-598. doi.org/10.1017/S0003598X00067971.

Higham, C.F.W., T.F.G. Higham and K. Douka. 2014. The chronology and status of Non Nok Tha, northeast Thailand. Journal of Indo-Pacific Archaeology 34: 61-75. doi.org/10.7152/jipa.v34i0.14719.

Hung, H.-c. and M. Carson. 2014. Foragers, fishers and farmers: origins of the Taiwanese Neolithic. Antiquity 88: 1115-1131. doi.org/10.1017/S0003598X00115352.

Kanginkudru, S., M. Metta, R.D. Jakati and J. Nagaraju. 2008. Genetic evidence from Indian red jungle fowl corroborates multiple domestication and modern day chicken. BioMed Central Evolutionary Biology 8. doi:10.1186/1471-2148/8/174.

Kijngam, A. 2011. The mammalian fauna. In C.F.W Higham, and A. Kijngam (eds), The Origins of the Civilization of Angkor, vol. IV, The Excavation of Ban Non Wat. Part II: The Neolithic Occupation, pp. 189-197. Bangkok: The Thai Fine Arts Department.

Kirch, P.V. 1987. Lapita and Oceanic cultural origins: excavations in the Mussau Islands, Bismarck Archipelago, 1985. Journal of Field Archaeology 14(2): 163-180. doi. org/10.1179/009346987792208493.

Kirch, P.V. 1997. The Lapita Peoples. Oxford: Blackwell.

- 2010. Peopling of the Pacific: A holistic anthropological perspective. Annual Review of Anthropology 39: 131-148. doi.org/10.1146/annurev.anthro.012809.104936.

Lape, P. 2000. Political dynamics and religious change in the late pre-colonial Banda Islands, eastern Indonesia. World Archaeology 32(1): 138-155. doi.org/10.1080/004382400409934.

Larson, G. and D.Q. Fuller. 2014. The evolution of animal domestication. Annual Review of Ecology, Evolution and Systematics 45: 115-136. doi.org/10.1146/annurev-ecolsys-110512-135813.

Larson. G., K. Dobney, U. Albarella, M. Fang, E. Matisoo-Smith, J. Robins, S. Lowden, H. Finlayson, T. Brand, E. Willerslev, P. Rowley-Conwy, L. Andersson and A. Cooper. 2005. Worldwide phylogeography of wild boar reveals multiple centers of domestication. Science 307: 1618-1621. doi. org/10.1126/science.1106927. 
Larson, G., T. Cucchi, M. Fujita, E. Matisoo-Smith, J. Robins, A. Anderson, B. Rolett, M. Spriggs, G. Dolman, T.-H. Kim, T.H.T. Nguyen, E. Randi, M. Doherty, R. Awe Due, R. Bollt, T. Djubiantono, B. Griffin, M. Intoh, E. Keane, P. Kirch, K.-T. Li, M. Morwood, L.M. Pedriña, P.J. Piper, R.J. Rabett, P. Shooter, G. Van den Bergh, E. West, S. Wickler, J. Yuan, A. Cooper and K. Dobney. 2007. Phylogeny and ancient DNA of Sus provides new insights into Neolithic expansion in Island Southeast Asia and Oceania. Proceedings of the National Academy of Sciences 104(12): 4834-4839. doi.org/10.1073/pnas.0607753104.

Larson, G., R. Liu, X. Zhao, J. Yuan, D. Fuller, L. Barton, K. Dobney, Q. Fan, Z. Gu, Z., X.-H. Liu, Y. Luo, P. Lv, L. Andersson and N. Li. 2010. Patterns of East Asian pig domestication, migration, and turnover revealed by modern and ancient DNA. Proceedings of the National Academy of Sciences 107(17): 7686-7691. doi.org/10.1073/pnas.0912264107.

Larson, G., E.L.K. Karlsson, A. Perri, M.T. Webster, S.Y.W. Ho, J. Peters, P.W. Stahl, P.J. Piper, F. Lingaas, M. Fredholm, K.E. Comstock, J.F. Modiano, C. Schelling, A.I. Agoulnik, P.A. Leegwater, K. Dobney, J.-D. Vigne, C. Villa, L. Andersson and K. Lindblad-Toh. 2012. Rethinking dog domestication by integrating genetics, archaeology, and biogeography. Proceedings of the National Academy of Sciences 109(23): 8878-8883. doi.org/10.1073/pnas.1203005109.

Lewis, H., V. Paz, M. Lara, H. Barton, P. Piper, J. Ochoa, T. Vitales, A.J. Carlos, T. Higham, L. Neri, V. Hernandez, J. Stevenson, E. C. Robles, A. Ragragio, R. Padilla, W.S. II and W. Ronquillo. 2008. Terminal Pleistocene to mid-Holocene occupation and an early cremation burial at Ille Cave, Palawan, Philippines. Antiquity 82: 318-335. doi.org/10.1017/S0003598X00096836.

Liu, Y.-P., G.-S. Wu, Y.-G. Yao, Y.-W. Miao, G. Luikart, M. Baig, A. Beja-Pereira, Z.-L. Ding, M.G. Palanichamy and Y-P. Zhang. 2006. Multiple maternal origins of chickens: Out of the Asian jungles. Molecular Phylogenetics and Evolution 38: 12-19. doi.org/10.1016/j.ympev.2005.09.014.

Lloyd-Smith, L., G. Barker, H. Barton, J. Cameron, F. Cole, C. Doherty, C. Hunt, J. Krigbaum, H. Lewis, J. Manser, V. Paz, P.J. Piper, G. Rushworth and K. Szabó. 2013. 'Neolithic' societies c. 4000-2000 years ago: Austronesian farmers? In G. Barker (ed.), Rainforest Foraging and Farming in Island Southeast Asia: The Archaeology and Environmental History of the Niah Caves, Sarawak, Niah Cave Project Monographs Series, pp. 255-298. Cambridge: McDonald Institute for Archaeological Research.

Lu, P. 2010. Zooarchaeological Study on the Shell Middens in the Yong Valley of Guangxi. Unpublished $\mathrm{PhD}$ dissertation, Institute of Archaeology, of Chinese Academy of Social Sciences, Beijing (in Chinese).

Lum, K.J., J.K. McIntyre, D.L. Greger, K.W. Huffman and M.G. Vilar. 2006. Recent Southeast Asian domestication and Lapita dispersal of sacred male pseudohermaphroditic 'tuskers' and hairless pigs of Vanuatu. Proceedings of the National Academy of Sciences 103(46): 17190-17195. doi.org/10.1073/ pnas.0608220103.

Macintosh, J.W.G. 1964. A 3,000 year old dingo skeleton from Shelter 6, In D.J. Mulvaney, G.H. Lawton and C.R. Twidale (eds), Archaeological Excavation of Rock Shelter no. 6 Fromm's Landing, South Australia. Proceedings of the Royal Society of Victoria 77: 479-516.

Matisoo-Smith, E. 2007. Animal translocations, genetic variation and the human settlement of the Pacific. In J.S. Friedlaender (ed.), Genes, Language and Culture History in the Southwest Pacific, pp. 157-170. Oxford: Oxford University Press. doi.org/10.1093/acprof:o so/9780195300307.003.0010.

Matsumura, H and M.F. Oxenham. 2011. Introduction: Man Bac biological research objectives In M.F. Oxenham, H. Matsumura and K.D. Nguyen (eds), Man Bac: The Excavation of a Neolithic Site in Northern Vietnam, pp. 1-8. Terra Australis 33. Canberra: ANU E Press. 
McCoy, P.C. and P.L. Cleghorn. 1988. Archaeological excavations on Santa Cruz (Nendö), southeast Solomon Islands: Summary report. Archaeology in Oceania 23(3): 104-115. doi. org/10.1002/j.1834-4453.1988.tb00197.x.

Medway, L. 1973. The antiquity of domesticated pigs in Sarawak. Journal of the Malaysian Branch of the Royal Asiatic Society 46(2): 169-178.

Meijer, H.J.M., T. Sutikna, E. Wahyu Saptomo, R. Awe Due, Jatmiko, S. Wasisto, H.F. James, M.J. Morwood and M.W. Tocheri. 2013. Late Pleistocene-Holocene non-passerine avifauna of Liang Bua (Flores, Indonesia). Journal of Vertebrate Paleontology 33(4): 877-894. doi.org/10.1080/02724634.2 013.746941 .

Mijares A.S.B. 2006. Unearthing Prehistory. The Archaeology of Northeastern Luzon, Philippine Islands. BAR International Series 1613. Oxford: Oxbow.

Milham, P. and P. Thompson. 1976. Relative antiquity of human occupation and extinct fauna at Madura Cave, southeastern Australia. Mankind 10: 175-180. doi.org/10.1111/j.1835-9310.1976. tb01149.x.

O'Connor, S., A. Barham, K. Aplin, K. Dobney, A. Fairbairn and M. Richards. 2011. The power of paradigms: examining the evidential basis for early to mid-Holocene pigs and pottery in Melanesia. Journal of Pacific Archaeology 2(2): 1-25.

Ochoa, J., V. Paz, H. Lewis, J. Carlos, E. Robles, N. Amano, M.R. Ferreras, M. Lara, B. Vallejo Jr., G. Velarde, S.A. Villaluz, W. Ronquillo and W. Solheim II. 2014. The archaeology and palaeobiological record of Pasimbahan-Magsanib Site, northern Palawan, Philippines. Philippine Science Letters 7(1): 22-36.

Oskarsson, M.C.R., C.F.C. Klütsch, U. Boonyaprakob, A. Wilton, Y. Tanabe and P. Savolainen. 2011. Mitochondrial DNA data indicate an introduction through Mainland Southeast Asia for Australian dingoes and Polynesian domestic dogs. Proceedings of the Royal Society of London B: Biological Sciences 279: 967-974. doi.org/10.1098/rspb.2011.1395.

Oxenham, M.F., P.J. Piper, P. Bellwood, C.H. Bui, K.T.K. Nguyen. Q.M. Nguyen, F. Campos, C. Castillo, R. Wood, C. Sarjeant, N. Amano, A. Willis and J. Ceron. 2015. Emergence and diversification of the Neolithic of southern Vietnam: insights from coastal Rach Nui. Journal of Island and Coastal Archaeology 10(3): 309-338. doi.org/10.1080/15564894.2014.980473.

Pang, J.F., C. Kluetsch, X.J. Zou, A-B. Zhang, L.Y Luo, H. Angleby, A. Ardalan, C. Ekstrom, A. Sköllermo, J. Lundeberg, H. Matsumura, T. Leitner, Y-P. Zhang and P. Savolainen. 2009. mtDNA data indicate a single origin for dogs south of Yangtze River, less than 16,300 years ago, from numerous wolves. Molecular Biology and Evolution 26: 2849-2864. doi.org/10.1093/molbev/ msp195.

Patte, E. 1932. Le Kjokkenmodding neolithique de Da But et ses sepultures. Bulleting de la Société Géologique de l'Indochiné 19(3): 24-35.

Pawley, A. 1966. Polynesian languages: A subgrouping based on shared innovations in morphology. Journal of the Polynesian Society 75: 39-64.

Pawley, A.K. and R.C. Green. 1975. Dating the dispersal of Oceanic languages. Oceanic Linguistics 12(1): $1-67$.

Petchey, F., M. Spriggs, S. Bedford, and F. Valentin. 2015. The chronology of occupation at Teouma, Vanuatu: Use of a modified chronometric hygiene protocol and Bayesian modeling to evulate midden remains. Journal of Archaeological Science: Reports 4: 95-105. doi.org/10.1016/j.jasrep.2015.08.024. 
Piper, P.J. and M.F. Oxenham. 2014. Of prehistoric pioneers: the establishment of the first sedentary settlements in the Mekong Delta region of southern Vietnam during the period 2000-1500 cal. BC. In K. Boyle, R. Rabett and C. Hunt (eds), Living in the Landscape: Essays in Honour of Graeme Barker (McDonald Institute Monographs), pp. 209-226. Cambridge: McDonald Institute for Archaeological Research.

Piper, P.J., H.-c. Hung, F.Z. Campos, P. Bellwood and R. Santiago. 2009. A 4000 year old introduction of domestic pigs into the Philippine Archipelago: implications for understanding routes of human migration through Island Southeast Asia and Wallacea. Antiquity 83: 687-695. doi.org/10.1017/ S0003598X00098914.

Piper, P.J., J. Ochoa, E. Robles, H. Lewis and V. Paz. 2011. Palaeozoology of Palawan Island, Philippines. Quaternary International 233: 142-158. doi.org/10.1016/j.quaint.2010.07.009.

Piper, P.J., N. Amano, S. Yang and T.P. O'Connor. 2013. The terrestrial vertebrate remains. In P. Bellwood, and E. Dizon (eds), 4000 Years of Migration and Cultural Interaction: Archaeology in the Batanes Islands, Northern Philippines, pp. 169-200. Terra Australis 40. Canberra: ANU E Press.

Piper, P.J., F.Z. Campos, D.N. Kinh, N. Amano, M. Oxenham, B.C. Hoang, P. Bellwood and A. Willis. 2014. Early evidence for pig and dog husbandry from the Neolithic site of An Son, Southern Vietnam, International Journal of Osteoarchaeology 24: 68-78. doi.org/10.1002/oa.2226.

Pugach, I., F. Delfin, E. Gunnarsdóttir, M. Kayser, M. Stoneking. 2013. Genome-wide data substantiate Holocene gene flow from India to Australia. Proceedings of the National Academy of Sciences 110: 1803-1808. doi.org/10.1073/pnas.1211927110.

Rispoli, F. 2007. The incised and impressed pottery style of Mainland Southeast Asia: Following the paths of neolithization. East and West 57(1-4): 235-304.

Robles, E., P.J. Piper, J. Ochoa, H. Lewis, V. Paz and W. Ronquillo. 2015. Late Quaternary sea level changes and the palaeohistory of Palawan Island, Philippines. Journal of Island and Coastal Archaeology 10(1): 76-96. doi.org/10.1080/15564894.2014.880758.

Sacks, B.N., S.K. Brown, D. Stephens, N.C. Pedersen, J.-T. Wu and O. Berry. 2013. Y chromosome analysis of dingoes and Southeast Asian village dogs suggests a Neolithic continental expansion from Southeast Asia followed by multiple Austronesian dispersals. Molecular Biology and Evolution 30: 1103-1108. doi.org/10.1093/molbev/mst027.

Salvolainen, P., T. Leitner, A.N. Wilton, E. Matisoo-Smith and J. Lundeberg. 2004. A detailed picture of the origin of the Australian dingo, obtained from the study of mitochondrial DNA. Proceedings of the National Academy of Sciences 101(33): 12387-12390. doi.org/10.1073/pnas.0401814101.

Sawada, J., K.T. Nguyen and A.T. Nguyen. 2011. Faunal remains at Man Bac. In M.F. Oxenham, H. Matsumura and K.D. Nguyen (eds), Man Bac: The excavation of a Neolithic Site in Northern Vietnam, pp. 105-116. Terra Australis 33. Canberra: ANU E Press.

Shannon, L.M., R.H. Boyko, M. Castelhano, E. Corey, J.J. Hayward, C. McLean, M.E. White, M.A. Said, B.A. Anita, N.I. Bondjengo, J. Calero, A. Galov, M. Hedimbi, B. Imam, R. Khalap, D. Lally, A. Masta, K.C. Oliviera, L. Perez, J. Randall, Nguyen, M.T., F.J. Trujillo-Cornejo, C. Valeriano, N.B. Sutter, R.J. Todhunter, C.D. Bustamante and A.R. Boyko. 2015. Genetic structure of village dogs reveals Central Asian domestication origin. Proceedings of the National Academy of Sciences 112(44): 13639-13644. doi.org/10.1073/pnas.1516215112.

Simanjuntak, T., M.J. Morwood, F.S. Intan, I. Machmud, K. Grant, N. Somba, B. Akw, D.W. Utomo. 2008. Minanga Sipakko and the Neolithic of the Karama Valley. In T. Simanjuntak (ed.), Austronesian in Sulawesi, pp. 57-76. Depok: Center for Prehistoric and Austronesian Studies. 
Storey, A.A., T. Ladefoged and E.A. Matisoo-Smith. 2008. Counting your chickens: Density and distribution of chicken remains in archaeological sites of Oceania. International Journal of Osteoarchaeology 18: 240-261. doi.org/10.1002/oa.947.

Storey, A.A, M. Spriggs, S. Bedford, S.C. Hawkins, J. Robins, L. Huynen and E. Matisoo-Smith. 2010. Mitochondrial DNA from 3000-year old chickens at the Teouma site, Vanuatu. Journal of Archaeological Science 37: 2459-2468. doi.org/10.1016/j.jas.2010.05.006.

Storey, A.A., J.S. Athens, D. Bryant, M. Carson, K. Emery, S. deFrance, C. Higham, L. Huynen, M. Intoh, S. Jones, P.V. Kirch, T. Lagefoged, P. McCoy, A. Morales-Muñiz, D. Quiroz, E. Reitz, J. Robins, R. Walter and E. Matisoo-Smith. 2012. Investigating the global dispersal of chickens in prehistory using ancient mitochondrial DNA signatures. PLoS One 7(7): 1-11. doi.org/10.1371/ journal.pone.0039171.

Storey, A.A., D. Quiroz, N. Beavan and E. Matisoo-Smith. 2013. Polynesian chickens in the New World: a detailed application of a commensal approach. Archaeology in Oceania 42(2): 101-119. doi. org/10.1002/arco.5007.

Storm, P. 2001. Resten van een hond uit de vindplaats Hoekgrot (Java). Cranium 18(1): 31-44 (in Dutch).

Summerhayes, G.R. 2007. The rise and transformations of Lapita in the Bismarck Archipelago, In S. Chiu and C. Sand (eds), From Southeast Asia to the Pacific. Archaeological Perspectives on the Austronesian Expansion and the Lapita Cultural Complex, pp. 141-184. Taipei: Academica Sinica.

Swadling, P., J. Chappell, G. Francis, N. Araho and B. Ivuyo. 1989. A Late Quaternary inland sea and early pottery in Papua New Guinea. Archaeology in Oceania 24: 106-109. doi. org/10.1002/j.1834-4453.1989.tb00219.x.

Szabó, K., F. Cole, L. Lloyd-Smith, G. Barker, C. Hunt, P.J. Piper and C. Doherty. 2013. The 'Metal Age' at the Niah Caves, c. 2000-500 years ago. In G. Barker (ed.), Rainforest Foraging and Farming in Island Southeast Asia: The Archaeology and Environmental History of the Niah Caves, Sarawak, pp. 299-340. Niah Cave Project Monographs. Cambridge: McDonald Institute for Archaeological Research.

Thomson, V.A., O. Lebrasseur, J.J. Austin, T.L. Hunt, D.A. Burney, T. Denham, N.J. Rawlence, J.R. Wood, J. Gongora, L. Girdland Flink, A. Linderhol, K. Dobney, G. Larson and A. Cooper. 2014. Using ancient DNA to study the origins and dispersal of ancestral Polynesian chickens across the Pacific. Proceedings of the National Academy of Sciences 111: 4826-4831. doi.org/10.1073/ pnas. 1320412111.

Tsang, C.H., K.T. Li and C.Y. Chu. 2006. Footprints of Ancestors. Tainan: Tainan County Government (in Chinese).

Valentin, F., F. Détroit, M.J.T. Spriggs and S. Bedford. 2015. Early Lapita skeletons from Vanuatu show Polynesian craniofacial shape: Implications for Remote Oceanic settlement and Lapita origins. Proceedings of the National Academy of Sciences 113(2): 292-297. doi.org/10.1073/pnas.1516186113.

van den Bergh, G. Rokus Due Awe, H.J.M. Meijer, K. Szabó, L.W. van den Hoek Ostende, M.J. Morwood, T. Sutikna, E.W. Saptomo, P.J. Piper and K. Dobney. 2009. The Liang Bua faunal remains: a 95kyr sequence from Flores, East Indonesia. Journal of Human Evolution 57: 527-537. doi.org/10.1016/j.jhevol.2008.08.015.

Veth, P., M. Spriggs and S. O’Connor. 2005. Continuity in tropical cave use: examples from East Timor and the Aru Islands, Maluku. Asian Perspectives 44(1): 180-192. doi.org/10.1353/asi.2005.0015. 
15. The Origins and Arrival of the Earliest Domestic Animals in Mainland and Island Southeast Asia

Wu, C.Y., Y.N. Jiang, H.P. Chu, S.H. Li, Y. Wang, Y.H. Li, Y. Chang and Y.T. Ju. 2007. The type 1 Lanyu pig has a maternal genetic lineage distinct from Asian and European pigs. Animal Genetics 38: 499-505. doi.org/10.1111/j.1365-2052.2007.01646.x.

Yang, S., H. Zhang, H. Mao, D. Yan, S. Lu, L. Lian, G. Zhao, Y. Yan, W. Deng, X. Shi, S. Han, S. Li, X. Wang and X. Gou. 2011. The local origin of the Tibetan pig and additional insights into the origin of Asian pigs. PLoS One 6(12): e28215. doi.org/10.1371/journal.pone.0028215.

Zhang, C. and H.-c. Hung. 2008. The Neolithic of southern China - origin, development and dispersal. Asian Perspectives 47(2): 299-329. doi.org/10.1353/asi.0.0004.

- 2010. The emergence of agriculture in southern China. Antiquity 84: 11-25. doi.org/10.1017/ S0003598X00099737. 
This text is taken from New Perspectives in Southeast Asian and Pacific Prehistory, edited by Philip J. Piper, Hirofumi Matsumura and David Bulbeck, published 2017 by ANU Press, The Australian National University, Canberra, Australia. 